\title{
MICHAL MAREŠ U RATU POSLIJE RATA (1945.-1947.): INTELEKTUALNI OTPOR IZGONU SUDETSKIH NIJEMACA
}

\section{František Šistek}

UDK: 821.162.3Mareš, M.:323.1(437.1=112.2)

Izvorni znanstveni članak

Sažetak: U okviru problematike poslijeratnog izgona sudetskih Nijemaca iz Čehoslovačke pojavljuje se i pitanje suočavanja čeških intelektualaca s izgonom. Ovaj prilog se fokusira na ličnost pisca i novinara Michala Mareša (1893.-1971.), koji je u svojim člancima kritizirao stanje u pograničnoj sudetskoj oblasti. U svojim tekstovima, koji su izlazili pretežno u tjedniku Dnešek, predstavljao je sudetske Nijemce kao obične i vrijedne radne ljude, kritizirao je metode primjenjivane tijekom njihovog izgona i upozoravao na nesagledive ekonomske posljedice koje će prouzrokovati prinudno iseljenje manjine koja je sačinjavala oko jedne trećine stanovništva čeških zemalja. Zbog svojih je tekstova u jesen 1946. isključen iz Komunističke partije i krivično gonjen. Sudski proces protiv Mareša izazvao je veliku pažnju. U ljeto 1947. Mareš je oslobođen svih optužbi. Nakon komunističkog puča u veljači 1948. godine, Mareš je uhapšen i osuđen na sedam godina teške robije i gubitak građanskih prava.

Ključne riječi: Michal Mareš, Čehoslovačka, sudetski Nijemci, 1945.-1947., etničko čišćenje, nacionalizam, anarhizam, komunizam, intelektualni otpor

D roblematika poslijeratnog izgona sudetskih Njemaca iz Čehoslovačke predstavlja jednu od ključnih tema suvremene češke historiografije. Dok su njemački povjesničari ovoj temi posvećivali odgovarajuću pažnju znatno ranije, u službenoj se čehoslovačkoj historiografiji, zbog stroge režimske kontrole znanstvenog diskursa, sve do 1989. radilo o tabu temi. Debata o progonu sudetskih Nijemaca je ipak započela već 70 -ih i 80-ih godina, prvenstveno u disidentskim krugovima povjesničara, esejista, fllozofa i novinara te $u$ emigraciji. Ključni doprinos temeljnom preispitivanju i novom istraživanju dali su, između 
ostalih, povjesničari Jan Křen, ${ }^{1}$ Ján Mlynárik-Danubius ${ }^{2}$ i Milan Hübl ${ }^{3}$, kao i trojica autora kritičke povijesti modernog češkog naroda, koji su nastupali pod zajedničkim pseudonimom Podiven (povjesničar Milan Otáhal, politolog Petr Pithart i psiholog Petr Př́hoda). ${ }^{4}$

Period nakon 1989. konačno je omogućio slobodu znanstvenih istraživanja i javnih diskusija o izgonu sudetskih Nijemaca. Desetljećima tabuizirana tema dobila je znatan i dugotrajan odjek u postkomunističkoj politici i kulturi. Intenzivno se razvija suradnja čeških, njemačkih i austrijskih povjesničara. Češko-njemačka komisija povjesničara, osnovana 1990. godine, postigla je već devedesetih godina konsenzus oko najvažnijih kontroverznih pitanja, prije svega oko brojeva deportiranih i žrtava poslijeratne odmazde. ${ }^{5}$ Tema izgona sudetskih Nijemaca ni danas nije iscrpljena. Posebno u lokalnim arhivima postoji još uvijek znatna količina nedovoljno istraženih izvora, primjenjuju se metode oralne historije itd. Oralna historija kao i mikrohistorija dobile su u češkoj akademskoj sredini puni legitimitet tek nakon 1989. godine. Pored ostalog, zajednički im je metodološki pristup s naglaskom na konkretnom povijesnom iskustvu pojedinca i njegovoj subjektivnoj interpretaciji događaja. Zajedničko im je i fokusiranje na manju ljudsku zajednicu (skupinu pojedinaca, selo, mikroregiju itd.). Dijele i interes za bavljenje „velikim povijesnim pitanjima” u konkretnim lokalnim uvjetima. Posljednjih godina među povjesničarima ovakva usmjerenja posebno se ističu Tomáš Staněk, Adrian von Arburg ${ }^{6}$ i Matěj Spurni.

Poznatim izvorima se istovremeno postavljaju nova pitanja. Za razliku od 1990-ih godina, kad su se, na primjer, tek utvrđivale činjenice u vezi s brojem stradalih i iseljenih pripadnika njemačke manjine, kada se rekonstruiralo promjene u politici federalnih državnih institucija te raspravljalo o odgovornosti vodećih ličnosti poput predsjednika Edvarda Beneša, istraživačko težište do danas se pomiče, pored ostalog, prema istraživanjima lokalnih situacija u različitim dijelovima pograničja, imajući na umu da su postojale osjetne mjesne razlike u odnosu spram njemačkih zajednica, prema problemima u vezi $s$,kolonizacijom" i ponovnim naseljavanjem opustjelih područja. Svi su se ti procesi, naime, zbivali simultano. Posebnu pozornost izaziva sudbina Nijemaca koji nisu bili deportirani. Jedno od najvažnijih istraživačkih pitanja danas je svakako suočavanje samog češkog društva s izgonom sudetskih Nijemaca: jesu li se, odnosno u kojoj mjeri i u kojim okolnostima, na

Jan Ǩ̌EN, Konfliktni společenství. Češi a Němci 1780-1918, Toronto 1989.

Ján MLYNÁRIK, Diaspora historiografie. Štúdie, články a dokumenty $k$ dejinám československej historiografie v rokoch 1969-1989, Praha 1998.; Ján MLYNÂRIK, Causa Danubius, Praha 2000.

Milan HÜBL, Česí, Slováci a jejich sousedé. Úvahy, studie a polemiky z let 1979-1989, Praha 1990.

PODIVEN, Češi v dějinách nové doby (1848-1939), Praha 1991.

„Stanovisko Společné česko-německé komise historiků k odsunovým ztrátám. Stellungnahme der Gemeinsamen deutsch-tschechischen Historikerkommission zu den Vertreibungsverlusten”, Soudobé dějiny, 3/1996., br. 4, 600.603.

6 Posebno treba spomenuti ediciju dokumenata iz čeških arhiva (do sada tri toma). Vidi: Adrian von ARBURG Tomáš STANĚK (ur.), Vysidlení Němcư a proměny českého pohraniči 1945-1951: dokumenty z českých archivů. Dỉl I., Češi a Němci do roku 1945: úvod k edici, Středokluky 2010.; Adrian von ARBURG - Tomáś STANĚK (ur.), Vysídlení Némcũ a promény českého pohraničí 1945-1951: dokumenty z českých archivü. Díl II, sv. 1, Duben-srpen/zárí 1945: „Divoký odsun” a počátky osidlování, Středokluky 2011.; Adrian von ARBURG - Tomáš STANĚK (ur.), Vysídlení Nëmcù a promény českého pohraničí 1945-1951: dokumenty z českých archivü. Díl II., sv. 3, Akty hromadného násilí v roce 1945 a jejich vyšetřování, Středokluky 2010. Adrian von Arburg je švicarski povjesničar mlađe generacije koji predaje na Masarykovom sveučilištu u Brnu. Povjesničar Tomáš Staněk sustavno istražuje problematiku poslijeratnog progona i drugih „ekscesa” već od početka devedesetih. Vidi na primjer: Tomáš STANĚK, Odsun Němcù z Československa 1945-1947, Praha 1991.; Tomáš STANĚK, Poválečné „excesy” v českých zemích v roce 1945 a jejich vyšetřování, Praha 2005.

Matěj SPURNÝ, Nejsou jako my. Česká společnost a menšiny v pohraniči (1945-1960), Praha 2011. 
češkoj strani pojavljivali glasovi protiv izgona ili pokušaji da se pripadnici njemačke manjine zaštite pred odmazdom? Veći broj takvih slučajeva koji su do sada otkriveni vezan je za reakcije „običnih” ljudi.

Međutim, usprkos znatnom ograničenju medijskih sloboda u razdoblju 1945.-1948. i, takoreći, općenarodnom konsenzusu da je iseljenje čitave njemačke manjine iz Sudeta poželjno, u tadašnjem javnom diskursu su se ipak pojavili kritični glasovi pojedinih intelektualaca. U ovom članku posvetit ćemo se slučaju Michala Mareša, pisca i novinara, koji se u poslijeratnom periodu vjerojatno dosljednije i najotvorenije zalagao za drugačiji pristup njemačkoj manjini i etnički miješanom pograničju. Njegov diskurs i dramatičan konflikt s Komunističkom partijom i dijelom državnog aparata rekonstruirat ćemo na osnovi nedavno objavljene građe, koja još uvijek nije privukla pažnju izvan akademskih krugova. O odjeku izvan granica Češke Republike da ni ne govorimo. ${ }^{8}$

\section{II.}

Demokratska i komunistička štampa su u prvim poslijeratnim mjesecima usprkos različitim političkim stavovima uglavnom dijelile slična nacionalistička gledišta u vezi navodno neophodnog izgona njemačke manjine. Kritika nekih aspekata progona pojavila se samo u dijelu nekomunističke štampe, posebno u nezavisnom tjedniku Dnešek, koji je od 1946. do 1948. izdavao Ferdinand Peroutka (1895.-1978.), ${ }^{9}$ ključna ličnost čehoslovačke žurnalistike. Dnešek je u tadašnjim okolnostima - za koje je bila karakteristična borba za vlast između političkih stranaka i njihovih glasila, a u kojoj su sve više prednjačili komunisti - predstavljao oazu slobodne diskusije. Sumnje u ispravnost tadašnje politike prema manjinama i otvorenu kritiku izgona sudetskih Nijemaca u prvim je poslijeratnim godinama u svojim tekstovima najjasnije izražavao pisac i novinar Michal Mareš (1893.-1971.), kome je Peroutka pružio prostor u svome tjedniku, nakon što je komunistički dnevnik Rudé právo odbio tiskati njegove kritične priloge. Mareš je među svojim suvremenicima bio dosta dobro poznat, ali i doživljavan kao pomalo eskcentrična ličnost javnog života. Tek u retrospektivnom pogledu, njegov životni put, nonkonformizam i humanistička stajališta koja je zastupao usprkos dominantnom diskursu svog vremena izazivaju povećani interes istraživača.

Michal Mareš rodio se 1893. kao Josef Mareš/Maresch u gradu Teplice (njemački Teplitz) u etnički miješanoj i bilingvalnoj sredini sjeverne Češke. ${ }^{10}$ Gimnaziju je pohađao u Pragu. Već je kao srednjoškolac postao aktivan u anarhističkim krugovima. Sa 17 godina, zbog sudjelovanja u međunarodnim protestima protiv pogubljenja španjolskog anarhi-

\footnotetext{
Marešovi članci kao i brojni drugi materijali vezani za njegov slučaj objavljeni su u knjizi Michal MAREŠ, Př́rcházim $z$ periferie republiky, Praha 2009. Ključni doprinos proučavanju Marešova života i rada dao je novinar, regionalni povjesničar i ekološki aktivist iz sjeverne Češke Pavel Koukal (*1944). Koukal je krajem šezdesetih godina osobno upoznao ostarjelog pisca i nakon njegove smrti sačuvao njegovu zaostavštinu. Zahvaljujući njegovoj inicijativi, Mareš je 1991. posthumno rehabilitiran i 1993. je na njegovoj rodnoj kući u Teplicama postavljena spomen-ploča. Krajem devedesetih, Koukal je također uredio i objavio Marešove memoare.

$9 \quad$ Peroutka je u međuratnom periodu uređivao legendarni časopis Př́tomnost, platformu liberalne građanske orijentacije, koja je bila kritična prema nacionalistima kao i komunistima. Razdoblje 1939.-1945. proveo je u nacističkim koncentracionim logorima Dachau i Buchenwald. Nakon 1948. živio je u egzilu, 1951.-1961. kao direktor češkog servisa Radija Slobodna Europa.

10 „Buntovničko” ime Michal je počeo koristiti kao adolescent, u čast svojih tadašnjih idola - ruskog filozofa anarhizma Mihaila Bakunjina i predvodnika češkog anarhističkog pokreta Michaela Káche (1874.-1940.).
} 
stičkog teoretičara Francisca Ferrera (1859.-1909.), izbačen je iz srednje škole. Zahvaljujući činjenici da je pored češkog i njemačkog jezika govorio francuski i talijanski, mogao je bez većih poteškoća - čak i s oskudnim novčanim sredstvima - proputovati Europu i Afriku. Nekoliko je godina proveo u Beču. Godine 1921. učlanio se u novoosnovanu Komunističku partiju, ali je istovremeno ostao vjeran anarhističkim uvjerenjima. Surađivao je s brojnim ljevičarskim i demokratskim listovima koji su izlazili na češkom ili njemačkom jeziku, od komunističke Tribune do liberalnog dnevnika Prager Tagblatt. Družio se s praškim piscima i novinarima poput Jaroslava Hašeka, Franza Kafke, Egona Erwina Kischa i mnogih drugih. Tridesetih godina pružao je pomoć njemačkim izbjeglicama koji su nakon dolaska nacista na vlast pronašli utočište u Čehoslovačkoj. Tijekom Drugog svjetskog rata bio je aktivan u pokretu otpora. ${ }^{11}$ Nakon oslobođenja 1945. godine, pripadnici NKVD-a su ga greškom uhapsili. Na saslušanju su se koristili čak i simulacijom njegove egzekucije. ${ }^{12}$ Oslobodivši se optužbe, izašao je iz zatvora i saznao da su njegovog oca u međuvremenu ubili pljačkaši iz tzv. Revolucionarnih gardi (Revoluční gardy - RG). ${ }^{13}$ Dakle, Mareš je ušao u „novo doba”, koje su njegovi ljevičarski sudrugovi iz predratne Čehoslovačke uglavnom nekritički podržavali pa i slavili, mnogo treznije. Osim toga, njegova dugogodišnja pripadnost bilingvalnom i hibridnom češko-njemačkom miljeu, prošlost boema i avanturista „bez dlake na jeziku”, anarhistička shvaćanja i odsustvo nacionalističkih predrasuda, omogućili su mu da mnoge poslijeratne pojave ocjenjuje s kritičke distance.

U atmosferi poslijeratnog nacionalizma, ograničene medijske slobode i apsolutnog političkog konsenzusa da je izgon sudetskih Nijemaca nužan i sasvim opravdan, potpuno otvorena kritika izgona Nijemaca i samog principa kolektivne krivice u javnom je diskursu bila nezamisliva i praktično neizvediva. U svojoj kritici stanja u pograničnim regijama, koja je bez obzira na izvjesna ograničenja bila znatno radikalnija i sustavnija nego što je bilo uobičajeno, Mareš je maksimalno iskoristio mogućnosti koje su pružale tadašnje limitirane medijske slobode, koje je - sudeći prema žestokim reakcijama na njegove tekstove - evidentno ipak prekoračio.

U Marešovim diskuzivnim strategijama može se uočiti nekoliko ciljeva. Prvu od njih predstavlja individualizacija i humanizacija kolektivnog neprijatelja. Autor je u svojim tekstovima sistematično prikazivao Nijemce „s ljudskim likom”, njihove pojedinačne sudbine i svakodnevno brige. Preostale sudetske Nijemce je prikazivao kao obične, konkretne ljude bez nacionalističkih osjećaja, ali s razvijenim radnim navikama i velikim sposobnostima. Marešovi principijelni argumenti protiv izgona Nijemaca bili su ekonomske prirode. Praktično je predlagao da se izgon makar privremeno zaustavi, odnosno, da se znatno poveća broj Nijemaca kojima će biti dozvoljeno da ostanu u zemlji, jer će u suprotnom naglo ispražnjene pogranične regije doživjeti ekonomski slom, koji će pogoditi čitavu Čehoslovačku. Treća strategija koja se provlači kroz Marešove tekstove je otvaranje mogućnosti prirodne asimilacije Nijemaca i isticanje povijesne veze i etničke izmiješanosti sudetskih Nijemaca s češkim stanovništvom. Diskurs o progonu Nijemaca u Marešovim je tekstovima bio usko

\footnotetext{
11 Mareš je tokom rata pomagao progonjenim Židovima, organizirajući, između ostalog, ilegalnu poštansku vezu s koncentracionim logorom Terezín/Theresienstadt.

12 Novinara su, kako se na kraju ispostavilo, uhitili umjesto druge tražene osobe istog ili sličnog imena.

13 Tzv. Revolucionarne garde nisu predstavljaje organizirane jedinice niti pokret. Uglavnom se radilo o manjim grupama ljudi koji su na rukav stavili crvenu traku s oznakom „RG” te su s oružjem u rukama sponatano počeli „uspostavljati red".
} 
povezan s kompleksnijom kritikom stanja u pograničju, uperenom protiv pripadnika „,lastite" nacije.

\section{III.}

Prvi Marešov prilog sa sudetskom temom, Hovory s Némci (Razgovor is Nijemcima), objavljen je u liberalnom dnevniku Svobodné slovo ${ }^{14} 15$. siječnja 1946. Izašao je, dakle, u prijelaznom i specifičnom periodu. „Divlja” faza izgona Nijemaca bila je u to vrijeme završena. Pogranične oblasti su već počeli naseljavati kolonisti iz češke unutrašnjosti, iz Slovačke, djelomično i ljudi češkog porijekla iz raznih, pretežno istočnoevropskih, država. U to je doba veći dio sudetskih Nijemaca još uvijek živio na svojim ognjištima, čekajući iseljenje ili neku drugu odluku o svojoj daljnjoj sudbini. Mareš je u spomenutom članku prezentirao glasove običnih Nijemaca, koji su govorili o svojim svakodnevnim brigama i strahovima nakon što su nacističke glavešine već odavno bile pobjegle. Autor je Nijemce predstavio kao radne ljude bez nacionalne mržnje, koji za čehoslovačku državu ne predstavljaju nikakvu prijetnju.

Slične je teze iznio u seriji članaka iz pograničja, objavljivanima u tjedniku Dnešek tijekom ljeta 1946. godine, pod nazivom Pricházím z periferie republiky (Dolazim s periferije republike). ${ }^{15}$ Prvi je članak izašao 27. lipnja 1946., dakle, u vrijeme kada su za razliku od zimskog perioda već trajale organizirane deportacije u suradnji s vlastima američke i sovjetske okupacijske zone u Njemačkoj. Serija je predstavljala svojevrsni putopis po raznim predjelima pograničja. Mareš je - često posredstvom glasova samih stanovnika regije - kritizirao postojeće stanje, prije svega lošu lokalnu administraciju i neracionalnu organizaciju unutrašnje kolonizacije. Na meti njegove kritike su često bili kolonisti-profiteri, ljudi bez radnih sposobnosti, zatim tzv. nacionalni administratori (národni správci) kao i pripadnici sigurnosnih snaga. Ovi su ljudi imali odlučujući udio u upravljanju i raspodjeli konfiscirane imovine sudetskih Nijemaca na lokalnoj razini. Većina ih se trudila svrstati što više Nijemaca među „nelojalne” i tome utjecati na odluku o njihovu hitnom iseljavanju. Na taj se način, prema njihovu mišljenju, radikalno, konačno i „za sva vremena” rješavalo njemačko manjinsko pitanje. Istovremeno se omogućavalo konfiskaciju praktično cjelokupne imovine iseljenih u korist države, ali i utjecajnih pojedinaca češke narodnosti. Mareš je svjesno zastupao suprotno gledište - nastojao je utjecati na usporavanje planiranih masovnih deportacija, odnosno na promjenu politike kojom bi se znatno većem broju sudetskih Nijemaca omogućilo da ostane u Čehoslovačkoj.

U nastavcima serije, koji su izlazili u vrijeme najintenzivnije faze deportacija, kojima su se često bukvalno preko noći ispraznila čitava sela i gradovi, ton Marešovih članaka bio je sve alarmantniji i emotivniji.

U prvom članku spomenute serije Michal Mareš je upozorio na više slučajeva „patriota”, koji su u programu češke kolonizacije u ruralnim područjima pograničja besplatno dobili vrijedna imanja, na kojima pak ništa ne rade. Umjesto toga, žive samo od prinudnog rada

\footnotetext{
Glavni urednik dnevnika bio je također Ferdinand Peroutka.

15 Pored perifernog položaja pograničja i tamošnjih stanovnika, naziv je predstavljao aluziju na njegovu zbirku pjesama Přcházim z periferie (Dolazim s periferije), koju je objavio dvadesetih godina.
} 
njemačkog stanovništva. U trenutku kad će tamošnji Nijemci biti konačno deportirani smatrao je Mareš - privreda koja se zasniva na ovoj osnovi, odmah će doživjeti kolaps. Bio je potpuno svjestan da se u poslijeratnoj atmosferi, sklonoj radikalnim rješenjima poput kolektivne odmazde, svaka pozitivna riječ o Nijemcima može smatrati izdajom:

Ovako nekako je govorio Jan Hus: Bog mi je svjedok da mi je pošten Nijemac miliji nego loš Čeh. Zbog sličnih bi riječi, ukoliko Hus danas ne bi bio odmah ponovno spaljen na lomači, sasvim sigurno bio prozvan heretikom. ${ }^{16}$

U više je navrata otvarao pitanje mogućeg prilagođavanja sudetskih Nijemaca, odnosno prirodne asimilacije tog dijela stanovništva. Ove su tendencije posebno vidljive u njegovoj reportaži o napornom radu rudara u ugljenokopima na sjeveru Češke, gdje su češki i njemački rudari radili zajedno u istim uvjetima prije rata, nakon aneksije oblasti od strane njemačkog Rajha 1938., kao i po okončanju rata. Mišljenje čeških rudara sažeo je sljedećim riječima:

S njemačkim drugarima smo uvijek radili zajedno. (...) Prema nama su se fino ponašali i tokom okupacije. (...) Kad se već mora provesti transfer, neka se onda ograniči na ljude suvišne i štetne. ${ }^{17}$

Sredinom ljeta Mareš se u reportaži iz sjeverne Češke ponovo osvrnuo na temu moguće prirodne asimilacije Nijemaca. Ovom je prilikom naglašavao da su se Nijemci i Česi u ovim krajevima vjekovima miješali bez obzira na porijeklo i jezik:

Vlakovi s tisućama deportiranih zemljoradničkih porodica, smještenih u vagonima za sto$\mathrm{ku}$, odlaze jedan za drugim u dio Njemačke pod patronatom Sjedinjenih Američkih Država. Stotine lijepe, zdrave djece u njima ima u svojim venama češku krv svojih dalekih predaka. Nikad neće dobiti priliku da postanu češki vojnici, zemljoradnici, radnici. (...) Prisjećam se ovom prilikom jednog Čeha, onog najvećeg, čija se majka do kraja života molila samo na njemačkom: T. G. Masaryka. (...) Poznavajući povijest ovih sve ispražnjenijih krajeva, duboko sam uvjeren da ne deportiramo izdajničke i opasne njemačke barbare. U venama mnogih od ovih germaniziranih ljudi vrije češka krv. ${ }^{18}$

Međutim, u unutrašnjosti zemlje je prevladavala nedovoljna obaviještenost o stvarnoj situaciji u pograničju. Većina stanovnika Češke i Moravske izvan pograničja odobravala je ideju brzog i potpunog izgona Nijemaca bez obzira na buduće posljedice, bez racionalnog plana kakva će biti dalja sudbina jedne trećine čeških zemalja. Mareš je iznio provokativan prijedlog:

Imam jedan recept. Svaki građanin koji se slaže sa deportacijom Nijemaca, neka dobije zakonsku obavezu da ih zamijeni na njihovim radnim mjestima, bilo kad i bilo gdje, tamo gdje će ga Republika poslati. I bez riječi. Tek onda ćemo povjerovati u iskrenost njegovih patriotskih osjećanja. ${ }^{19}$

Slika situacije u većini pograničnih mjesta koju je Mareš prezentirao u svojim člancima bila je izrazito negativna. Pograničje je prema njemu očito bilo na ivici ekonomske katastro-

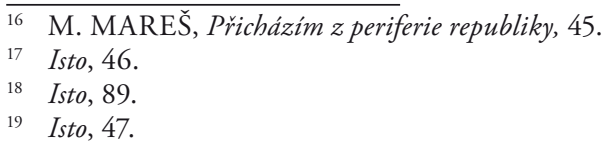


fe, iako su postojali i pozitivni primjeri u mjestima u kojima izgon njemačkog stanovništva dotad nije počeo, a radne su sposobnosti tamošnjeg stanovništva iskorištene na racionalan način. Tako je, na primjer, pohvalio lokalne vlasti u gradu Chebu (njem. Eger) na krajnjem zapadu Češke, u kojem još nisu prestale funkcionirati komunalne službe. Naveo je i upravu jedne tvornice iz gorja Šumava (njem. Böhmerwald) koja je zaposlila Čehe i Nijemce jedne pored drugih te je kao jedino poduzeće u regiji već bila dostigla predratni nivo proizvodnje. ${ }^{20}$ Međutim, potpuna slika je ipak bila znatno dramatičnija: mnoga sela i gradići su ostali kompletno bez stanovništva, a tamošnje su tvornice prestale s radom. Slična situacija zavladala je u izrazito ruralnim, pretežno planinskim predjelima, koji su pored toga što su uglavnom bili naseljeni gotovo isključivo Nijemcima također činili i tradicionalno najsiromašnije regije čeških zemalja. Toj se temi posvetio i detaljnije, opisujući situaciju u šumovitoj oblasti na češko-bavarsko-austrijskoj tromeđi:

Drvosječe su već praktično svi deportirani. Je li se uistinu moralo toliko žuriti da se ovi radni, za svoja ognjišsta duboko vezani ljudi deportiraju prije nego što se za njih pronašla adekvatna zamjena? I hoće li se uopće ikada pronaći? Dobrovoljne radne akcije nisu dovoljne, ove puste krajeve nitko ne želi naseliti. (...) Bradati Robinzoni sa sjekirom i testerom nisu znali govoriti ni češki ni pravi njemački, mnogi od njih čak nikad u životu nisu vidjeli vlak. Ipak su bili deportirani, iako to iz višeg državnog interesa nije baš bilo potrebno. (...) Ali kako reći istinu onima koji su gluhi? Spremni su da vas kamenuju, iako u suštini govorite sa pozicija najiskrenijeg patriotskog interesa. ${ }^{21}$

Nakon prvih Marešovih reportaža, redakcija tjednika Dně̌ek objavila je nekoliko pisama čitatelja, koji su se uglavnom slagali s autorom te su iznijeli brojne činjenice i nove primjere u korist njegovih zaključaka. Tokom ljeta 1946. Marešov ton u novim nastavcima serije Dolazim iz periferije republike postaje radikalniji. U ključnoj reportaži, koja je izašla 11. srpnja, autor je opisao protjerivanje njemačkog stanovništva iz sela Dolní Chobolice (njem. Nieder Koblitz) u plodnom dijelu sjeverne Češke. U selo, koje je zahvaljujući zemljoradnji bilo dosta prosperitetno, već je 1945. došla oružana grupa ljudi s periferije Praga s namjerom da ovdje osnuju „kolhoz”. Starosjedioci su dobili deset minuta da pokupe nekoliko kilograma stvari, a potom su protjerani. Mareš je optužio češke došljake da su tom prilikom primjenjivali nacističke metode ponašanja. Godinu dana kasnije, nekada bogato selo - pisao je Mareš - bilo je opljačkano i opustošeno, a od „kolhoza” ni traga. Češki predstavnici sela reagirali su u pismu, objavljenom 1. kolovoza 1946., poričući Marešove tvrdnje. „Neka se češki pisac, koji na ovaj način blati vlastiti narod, iseli zajedno s Nijemcima”, navedeno je u reakciji. Potom je 10. kolovoza 1946. u lokalnim novinama Chebsko izašla karakteristična ogorčena reakcija:

Potpuno je neshvatljivo i neprihvatljivo da se pojavio „češki” novinar, koji u visokotiražnom dnevniku Dněsek na tako naivan način piše protiv transfera Nijemaca iz naše republike. Punih tisuću godina čekali smo ovu jedinstvenu povijesnu priliku i sad bi, ukoliko poslušamo gospodina Mareša, ovdje trebalo ostaviti Nijemce na miru samo zato, što na nekim mjestima nije pokošena trava?22 
Osim negativnih reakcija čitatelja i štampe pod jačim komunističkim utjecajem, uslijedio je udar državnog aparata. Mareš je bio optužen zbog klevete pripadnika policije u svojim tekstovima. Iznoseći svoju obranu na sudu 18. rujna 1946. godine, rezimirao je čitavu svoju dotadašnju javnu djelatnost. Govorio je hrabro i neustrašivo, bez pokušaja da se opravda ili umanji težinu svojih tvrdnji. U pozadini govora mogao se naslutiti njegov anarhistički prezir prema policiji. Govor je u cijelosti već idućeg dana tiskan u tjedniku Dnešek. Između ostalog, optuženi je u svom govoru javno postavio jedno od najvažnijih pitanja poslijeratnog perioda: je li nakon oslobođenja od nacističke okupacije uistinu došlo do obnove demokratskih sloboda? Naglasio je:

Ukoliko kod nas postoji stvarna sloboda, nikako ne mogu biti osuđen. Ukoliko je naša sloboda samo djelomična ili potpuno fiktivna, svejedno je kakva će biti konačna presuda. ${ }^{23}$

Govoreći o svojoj anarhističkoj prošlosti, usporedio je vladajući poludemokratski režim i surovu atmosfere poslijeratnog radikalizma s političkom klimom koja je vladala u zadnjim godinama navodno „trule” Austro-Ugarske Monarhije:

Kada me kao devetnaestogodišnjeg klinca udario oficir u policijskog stanici, uslijedila je prava bura u bečkom parlamentu i krivac je na kraju bio suspendiran s položaja na nekoliko godina. Danas, trideset pet godina kasnije, došli smo do situacije, da se više ni miš ne pomakne kad greškom ubiju čovjeka. ${ }^{24}$

Marešovo hrabro držanje na sudu i duhovit govor dobili su simpatije demokratskog djela javnosti, dok su komunistička glasila pojačala kampanju protiv njega. Ona se bila rasplamsala već krajem ljeta 1946. Mareš je dobio brojna pisma podrške njemu nepoznatih građana i nekih poznatih intelektualaca, na primjer protestanskog pastora, pedagoga i socijalnog radnika Přemysla Pittera (1895.-1976.) ili nadrealista i psihoanalitičara Bohuslava Brouka (1912. -1978.). Neka pisma sadrže tvrdnju da je podrška Marešovim stavovima u narodu bila znatno šira, ali su se mnogi zbog političke klime bojali javno oglasiti. U obranu svog autora stala su i glasila Dnešek i Svobodné noviny, koje je, kako je već rečeno, uređivao Ferdinand Peroutka, riskirajući time da postane još omraženiji sve agresivnijim komunistima. ${ }^{25}$ Peroutka je i dalje nastavio intenzivnu suradnju s optuženim autorom.

U listopadu 1946. godine, ovaj anarhistički aktivist i socijalist koji je pripadao uskom krugu najstarijih članova Komunističke partije (od osnivanja 1921.), službeno je isključen iz Partije. Nitko od starih suboraca nije stao u njegovu obranu. U svojoj javnoj reakciji Mareš nije izrazio žalost jer „današnja Partija više nije ista kao ona iz međuratnog perioda." ${ }^{26}$

U okviru kampanje protiv Mareša, autor serije Dolazim iz periferije republike ismijavan je između ostalog kao komična figura, kao sentimentalan i naivan čovjek jednog prevla-

\footnotetext{
Isto, 126.
}

Isto, 128.

25 Ministarstvo informacija, koje je bilo pod kontrolom komunista (ministar Václav Kopecký), zastrašivalo je redakcije nepodobnih glasila, prijetilo financijskim kaznama, na snazi je bio „zakon o povredi narodne časti” koji se mogao lako zloupotrebiti, izmišljali su se lažne prepreke itd. Demokršćanski časopis Obzory, koji je također upozoravao na slučajeve "našeg poslijeratnog gestapizma”, Ministarstvo informacija je, na primjer, pokušalo ukinuti pod izgovorom „nedostatka papira”. Petr BEDNARÍK, „Český tisk v letech 1945-1948”, Rozvoj české společnosti v Evropské unii, tom III, Média, Teritoriální studia, (ur. Jakub Končelík i dr.), Praha 2004., 132.-144.

26 M. MAREŠ, Pricházim z periferie republiky, 250.-252. 
danog vremena. Povode za satiričko karikiranje Marešove ličnosti komunistički pisci pronašli su i u drugim njegovim tekstovima, koji su iz današnjeg ugla imali jedan snažan, za svoje doba neobičan ekološki naglasak. Naime, Mareš se između ostalog zalagao za prava životinja i zaštitu prirode, protestirao je protiv znanstvenih eksperimenta na životinjama i slično. Protivio se i smrtnoj kazni, što je bilo sasvim kontradiktorno duhu tadašnjeg vremena - u prvim poslijeratnim godinama egzekucije nacista i kolaboracionista, nakon citavog jednog vijeka, ponovno su postale omiljeni javni spektakl. Protiv Mareša su pisani ne samo tekstovi polemičkog karaktera nego i satirične pjesme, poput pjesme Václava Lacine (1906.-1993.) O dobrém srdci anarchisty (O dobrom srcu anarhista), objavljene 8. listopada 1946. u komunističkom satiričnom listu Dikobraz. U njoj je u stihovima partijskog pjesnika izjednačen Marešov „sentimentalan” odnos prema deportiranim Nijemcima i napuštenim psima i mačkama, usprkos tome da su svi neizlječivo smrdljivi i bolesni. ${ }^{27}$

Samo dan kasnije u listu Tribuna Marešov je ugled osporio agresivni komunistički ideolog Gustav Bareš (prije rata Gustav Breitenfeld, 1910.-1979.) u članku Př́pad Michala Mareše (Slučaj Michala Mareša). Starog anarhista i internacionalista predstavio je kao pronjemačkog, čak prikriveno pronacističkog publicista koji pod svaku cijenu „pokušava spasiti Nijemce od posljedica poraza nacizma i blati obraz narodne policije, koja aktivno djeluje protiv Nijemaca, izdajica, profitera i kolaboracionista. ${ }^{.28}$ Kao uvijek do tada, Mareš se aktivno branio protiv tih optužbi. Osudio je šovinističku poslijeratnu atmosferu, u kojoj su potpuno izbrisane razlike među Nijemcima, tako da je praktično postalo nemoguće slobodno pisati o pozitivnoj i herojskoj ulozi antifašista njemačke nacionalnosti, od kojih su mnogi poginuli u obrani Čehoslovačke. Ismijavao je

(...) šovinizam Slavena Breitenfelda, koji zastupa političku ideologiju nezamislivu bez doprinosa Nijemaca Engelsa, Marxa, Liebknekchta, Thälmanna, Rose Luxemburg i gomile drugih. (...) Da, oni su vrijedni poštovanja, bez obzira na činjenicu da su to istovremeno Nijemci. (...) Zbog toga sam ja germanofil, a gospodin Bareš-Breitenfeld rođeni Slaven. Kakav ludi svijet! ${ }^{29}$

S obzirom na činjenicu da je progon Nijemaca 1947. već praktično završen, Mareš se u svojim publicističkim radovima bavio drugim temama - između ostalog, fokusirao se na kontroverznu pojavu poslijeratnog antisemitizma i poteškoće mnogih preživjelih Židova u nastojanju da povrate svoju imovinu. Također je objavljivao svjedočanstva o kršenju ljudskih prava u poratnim internacijskim logorima, tj. o temi koja je tek kasnije dobila veći odjek u javnosti. U vezi svojih članaka o situaciji u pograničju, nikad se nije pokajao i uvijek je dosljedno, često sa sarkazmom reagirao na optužbe svojih protivnika. 1947. godine Čehoslovačka je ipak još uvijek bar djelomično bila demokratska država. Sudski postupak protiv Mareša zbog uvrede pripadnika policije obustavljen je 18. lipnja, a optužba ocijenjena kao neutemeljena. ${ }^{30}$

Pobjeda nije bila dugotrajna. Komunistička partija Čehoslovačke je uspjela uspostaviti totalitarnu diktaturu nakon puča u veljači 1948. Za razliku od nekih drugih nekomu-

Dikobraz, 2/1946., br. 41, 2.

28 M. MAREŠ, Pricházim z periferie republiky, 225.

29 Isto, 227.-228.

30 Sve do veljače 1948. ministar unutrašnjih poslova bio je nekomunistički političar Prokop Drtina (1900.-1980.), predstavnik Narodne socijalističke partije. Bio je zagovornik radikalnog obračuna s pripadnicima njemačke manjine, ali je istovremeno branio slobodu govora. Nakon 1948. proveo je 12 godina u zatvoru. 


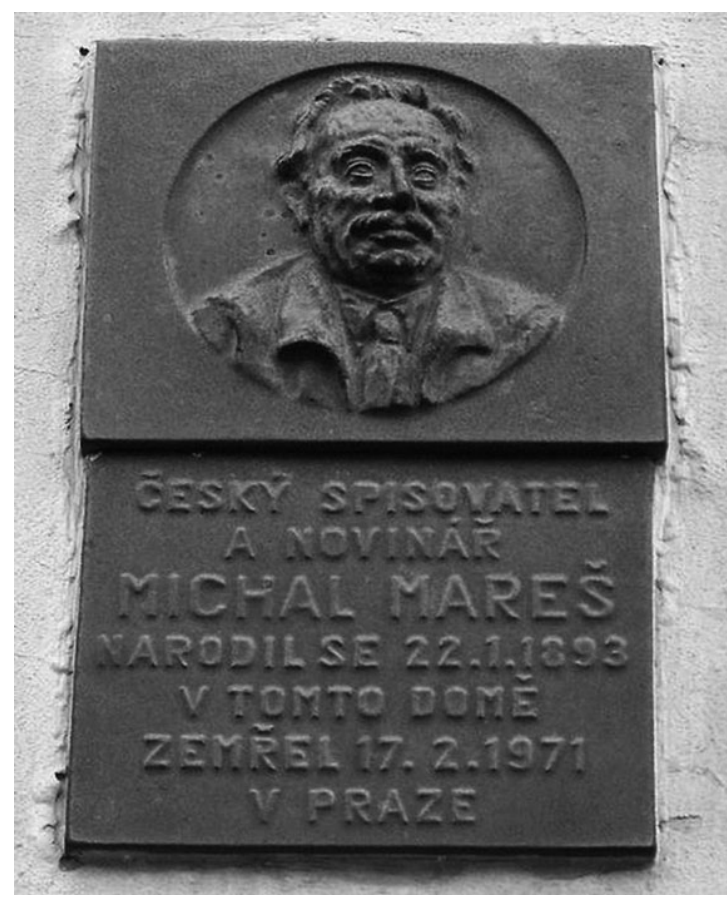

Slika 1. Zakašnjelo priznanje i naknadna rehabilitacija: spomen-ploča Michalu Marešu na njegovoj rodnoj kući u Teplicama, postavljena 1993. godine nističkih, kritički nastrojenih novinara, kao što su bili Ferdinand Peroutka i Pavel Tigrid, ${ }^{31}$ koji su u prvim danima nakon uvođenja diktature uspjeli pobjeći u emigraciju, Mareš je ostao u domovini. Nova vlast je uskoro iskoristila priliku da se konačno i nesmetano obračuna s ovim neustrašivim kritičarom. Mareš je uhićen 30. travnja $1948 .^{32}$ Između ostalog, optužen je da je „u svojim člancima širio lažnu propagandu i neistinite vijesti te vrijeđao narodnu policiju." 33 Dodatno obrazloženje optužnice teretilo ga je zbog odjeka njegovih tekstova u inozemstvu, čime je navodno „prouzrokovao otežavanje transfera Nijemaca iz naše države." ${ }^{34} \mathrm{Na}$ posljetku je Mareš 12. studenoga 1948. osuđen na sedam godina teške robije, uz konfiskaciju cjelokupne imovine i gubitak građanskih prava na deset godina. ${ }^{35} \mathrm{Iz}$ zatvora je izašao u ožujku $1955 .{ }^{36}$ Ostatak života proveo je u bijedi, pišući memoare, bez prihoda, bez mirovine i bez mogućnosti da išta objavljuje. ${ }^{37}$ Umro je u Pragu 1971. godine. Tek je 1991. Michal Mareš
ơven svih optužbi i potpuno rehabilitiran. odlukom Vrhovnog suda bio posthumno oslobođen svih optužbi i potpuno rehabilitiran.
Kao što je već rečeno, s retrospektivnog gledišta Marešova kritika izgona Nijemaca iz 1946.-1947. može se činiti nedovoljnom jer nije pogađala samu srž ideje kolektivne krivice nego prije svega pojedine negativne pojave vezane za cijeli proces iseljenja jedne „manjine” koja je predstavljala čak trećinu stanovništva čeških zemalja. Međutim, moramo uvijek biti

31 Pavel Tigrid (1917.-2003.), češki novinar, političar kršćanskodemokratske orijentacije i vodeća ličnost antikomunističkog egzila nakon 1948. Poslije 1989. godine radio je u uredu predsjednika Havela, a 1994.-1996. vršio je dužnost ministra kulture Češke Republike.

32 Još je u veljači 1948., nakon uvođenja komunističke diktature, kao prvi pisac uopće isključen iz Saveza čehoslovačkih pisaca.

33 M. MAREŠ, Pricházim z periferie republiky, 549.

34 Isto, 557. Ova optužba je uglavnom bila zasnovana na činjenici da su prijevodi izabranih Marešovih članaka početkom 1947. tiskani u „iredentističkom i antičehoslovačkom” časopisu Der Sozialdemokrat, koji je u Londonu uređivao Wenzel Jaksch (1896.-1966.), socijaldemokratski političar lojalan predratnoj čehoslovačkoj državi, koji se tek tijekom rata razišao s čehoslovačkom vladom u egzilu oko pitanja kolektivnog izgona sudetskih Njemaca, kojem se protivio.

35 Prema završnoj presudi, Mareš je službeno osuđen za navodnu pomoć jednom nacističkom zločincu u svibnju 1945. Vidi: Michal MAREŠ, Ze vzpominek anarchisty, reportéra a válečného zločince, Praha 1999., 369.-371.

36 Čak i u teškim zatvorskim uvjetima, Mareš je ostao vjeran svojim principima. Prilikom popisa 1949. godine, u jeku staljinističke antisemitske kampanje, deklarativno se izjasnio kao pripadnik židovske nacije, iako uopće nije bio židovskog porijekla.

37 Vidi: Michal MAREŠ, Ze vzpomínek anarchisty, reportéra a válečného zločince. Mareš je memoare pisao pretežno na njemačkom jeziku u nadi da će možda jednog dana izaći u inozemstvu jer je u domovini objavljivanje njegovih tekstova bilo zabranjeno sve do pada komunističkog režima. 
svjesni da su u samom poslijeratnom razdoblju postojala brojna ograničenja medijskih sloboda i da je piscu, glavnom uredniku kao i egzistenciji samog glasila prijetila sasvim realna i ozbiljna opasnost od strane jednog dijela državnog aparata. Uostalom, Marešova žestoka i otvorena kritika konkretnih, pojedinačnih pojava vezanih za progon Nijemaca bila je u svoje vrijeme shvaćena kao preradikalna čak i od strane nekih demokratski i humanistički orijentiranih novinara poput Pavla Tigrida. ${ }^{38}$ Što je najvažnije, komunistička diktatura u nastajanju u ovoj je naizgled djelomičnoj kritici prepoznala ozbiljnu, generalnu kritiku ideje izgona i novog totalitarnog poretka - poretka u koji je bio vješto ugrađen i nacionalistički element. Michal Mareš je brzo prepoznat i trajno obilježen kao opasan protivnik. Svoju kritiku je platio dugogodišnjim zatvorom i doživotnom zabranom javnog djelovanja. S obzirom na ove činjenice, umanjivanje značaja Marešovog hrabrog javnog angažmana u datim povijesnim okolnostima krajnje je neumjesno. Puna valorizacija Marešovog lika i djela vjerojatno tek predstoji.

\section{Opposing the Post-War Expulsion of the Sudeten- Germans from Czechoslovakia: the Case of Michal Mareš}

The expulsion of the large Sudeten German minority from Czechoslovakia after World War II was an important topic in Czech historiography of the post-Communist period. One interesting aspect of this wide and complex set of problems concerns the ways in which the ethnic Czechs reacted to the expulsion. Despite the apparent national consensus that the "ethnic unmixing" and "collective transfer" of the German minority represents the only possible solution for the long-term Czech-German national antagonism, aggravated by the Nazi occupation to the point where further coexistence of the two ethnic groups in one land seemed impossible, some Czech intellectuals already criticized certain aspects of the expulsion immediately after the war. This paper focuses on the personality and the discourse of Michal Mareš (1893-1971), left-wing (anarchist) writer and journalist, who systematically criticized the post-war mismanagement of the Czech border areas in the independent weekly Dnešek, pointed out the crimes comitted against members of the German minority and openly questioned the extent and rationality of the near-complete expulsion undertaken by Czechoslovak authorities between 1945 and 1947. In his articles, Mareš portrayed ordinary Sudeten Germans as decent, dilligent workers and farmers whose deportation was not politically justified and could cause serious economic and demographic problems. Mareš faced heavy backlash over a series of his articles published in the Dnešek, especially in Communist-controlled press. In the fall of 1946, he was expelled from the Communist party and faced a trial for alleged defamation of the police forces in his texts. The trial, as well as his previous articles, attracted great public attention. In the summer of 1947, Mareš was finally acquitted of all charges. However, after

38 Petr MIKŠÍČEK, „Pavel Koukal z Duchcova: Vzestup a pád centra kultury a vzdělanosti v 19. a 20. století na českém Severu. Životní př́iběh Karla Líma a Michala Mareše” (http://www.znkr.cz/clanek/500-pavel-koukal-z-duchcovavzestup-a-pad-centra-kultury-a-vzdelanosti-v-19-a-20-stoleti-na-ceskem-severu-Zivotni-pribeh-karla-lima-a-michala-marese-/). 
the final Communist takeover in February 1948, the journalist was soon arrested and tried again. This time, he was sentenced to seven years in prison and a loss of civil rights for 10 years. After his release in 1955, Mareš spent the rest of his life in poverty. His role has been reassesed and his post-war writings and memoirs published only after 1989. From today's perspective, it is evident that Michal Mareš was the most systematic and outspoken Czech opponent of the expulsion of the Sudeten German minority in the immediate post-war period. Out of a handful of intellectuals critical of the expulsion and its methods, he also paid the heaviest price for his courageous and humane reporting.

Keywords: Michal Mareš, Czechoslovakia, Sudeten Germans, 1945-1947, ethnic cleansing, nationalism, anarchism, communism, intellectual resistance

\section{$\cos$}

\section{Literatura}

Adrian von ARBURG - Tomáš STANĚK (ur.), Vysidlení Němců a promény českého pohraniči 19451951: dokumenty z českých archivio. Dil I., Češi a Němci do roku 1945: úvod k edici, Středokluky 2010.

Adrian von ARBURG - Tomáš STANĚK (ur.), Vysidlení Němců a promény českého pohraniči 19451951: dokumenty z českých archivů. Díl II, sv. 1, Duben - srpen/zárí 1945: „Divoký odsun” a počátky osidlování, Středokluky 2011.

Adrian von ARBURG - Tomáš STANĚK (ur.), Vysidlení Němců a proměny českého pohraniči 19451951: dokumenty z českých archivì. Díl II., sv. 3, Akty hromadného násili v roce 1945 a jejich vyšetrování, Středokluky 2010.

Petr BEDNǍ̌ÍK, „Český tisk v letech 1945-1948”, Rozvoj české společnosti v Evropské unii, tom III, Média, Teritoriálni studia, (ur. Jakub Končelík i dr.), Praha 2004., 132.-144.

Zdeněk BENEŠ et al., Rozumèt dějinám. Vývoj česko-německých vztahư na našem územív letech 1848-1948, Praha 2002.

Milan HÜBL, Češi, Slováci a jejich sousedé. Úvahy, studie a polemiky z let 1979-1989, Praha 1990.

Jan KŘEN, Konfliktni společenstvi. Češi a Němci 1780-1918, Toronto 1989.

Jaroslav KUČERA, Odsun nebo vyhnání? Sudetští Němci v Československu v letech 1945-1946, Jinočany 1992.

Václav KURAL, Konflikt misto společenstvi? Češi a Němci v československém státě 1918-1938, Praha 1993.

Václav KURAL, Misto společenství - konflikt! Češi a Němci ve Velkoněmecké ř́risi a cesta k odsunu, Praha 1994.

Michal MAREŠ, Ze vzpominek anarchisty, reportéra a válečného zločince, Praha 1999.

Michal MAREŠ, Pricházim z periferie republiky, Praha 2009.

Petr MIKŠÍČEK, „Pavel Koukal z Duchcova: Vzestup a pád centra kultury a vzdělanosti v 19. a 20. století na českém Severu. Životní příběh Karla Líma a Michala Mareše” (http://www.znkr. cz/clanek/500-pavel-koukal-z-duchcova-vzestup-a-pad-centra-kultury-a-vzdelanosti-v-19-a-20stoleti-na-ceskem-severu-Zivotni-pribeh-karla-lima-a-michala-marese-/).

Ján MLYNÁRIK, Diaspora historiografie. Štúdie, články a dokumenty k dejinám československej historiografie v rokoch 1969-1989, Praha 1998.

Ján MLYNÁRIK, Causa Danubius, Praha 2000.

PODIVEN, Čěsi v dějinách nové doby (1848-1939), Praha 1991. 
Milan ŘEPA, „The Czechs, Germans and Sudetenland: Historiographical Dispute in the 'Heart of Europe"', Disputed Territories and Shared Pasts: Overlapping National Histories in Modern Europe, (ur. Tibor Frank i Frank Hadler), Basingstoke 2011., 303.-328.

Matěj SPURNÝ, Nejsou jako my. Česká společnost a menšiny v pohraniči (1945-1960), Praha 2011. Tomáš STANĚK, Odsun Němcio z Československa 1945-1947, Praha 1991.

Tomáš STANĚK, Poválečné „excesy” v českých zemich v roce 1945 a jejich vyšetrování, Praha 2005. 


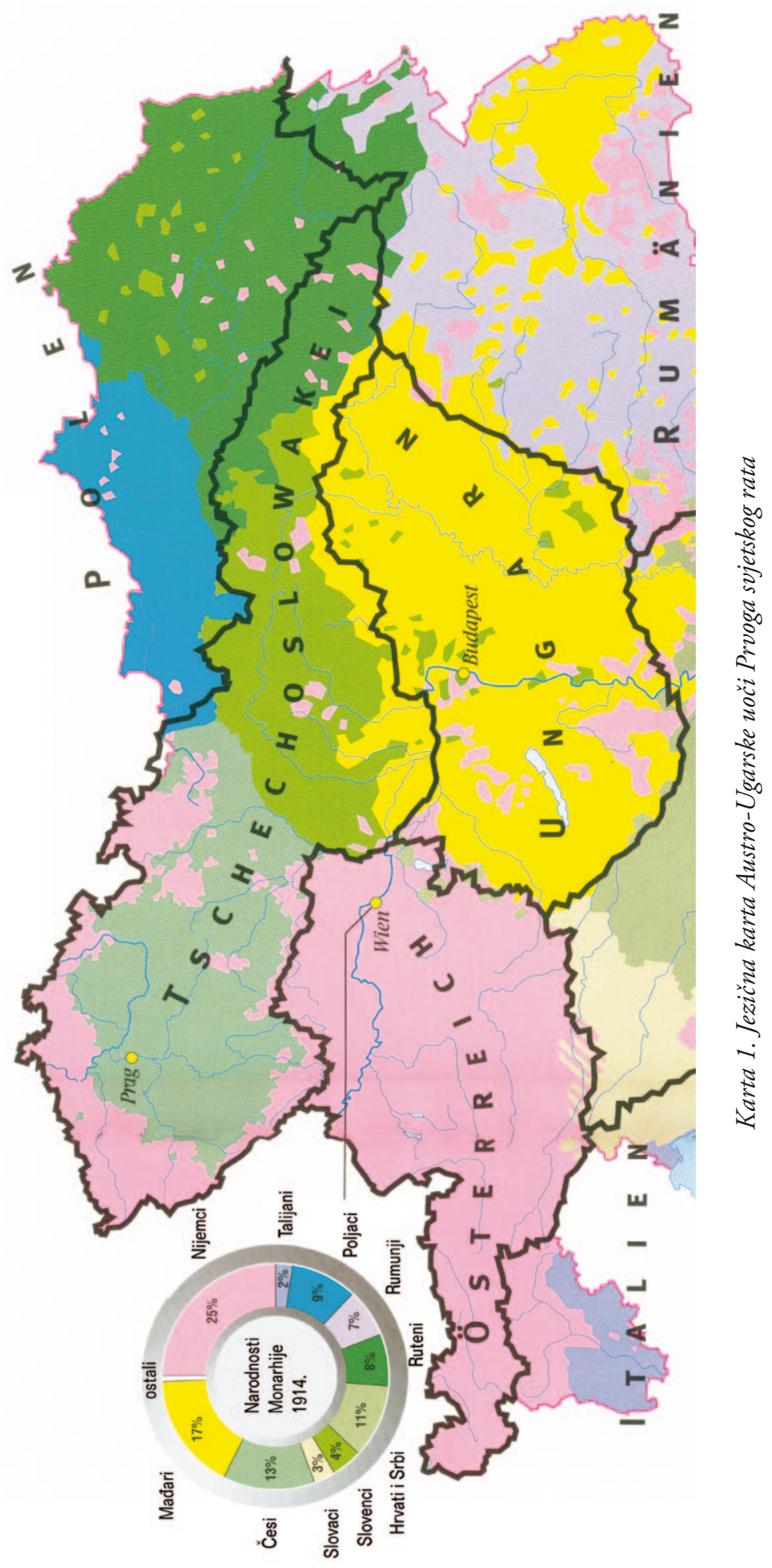




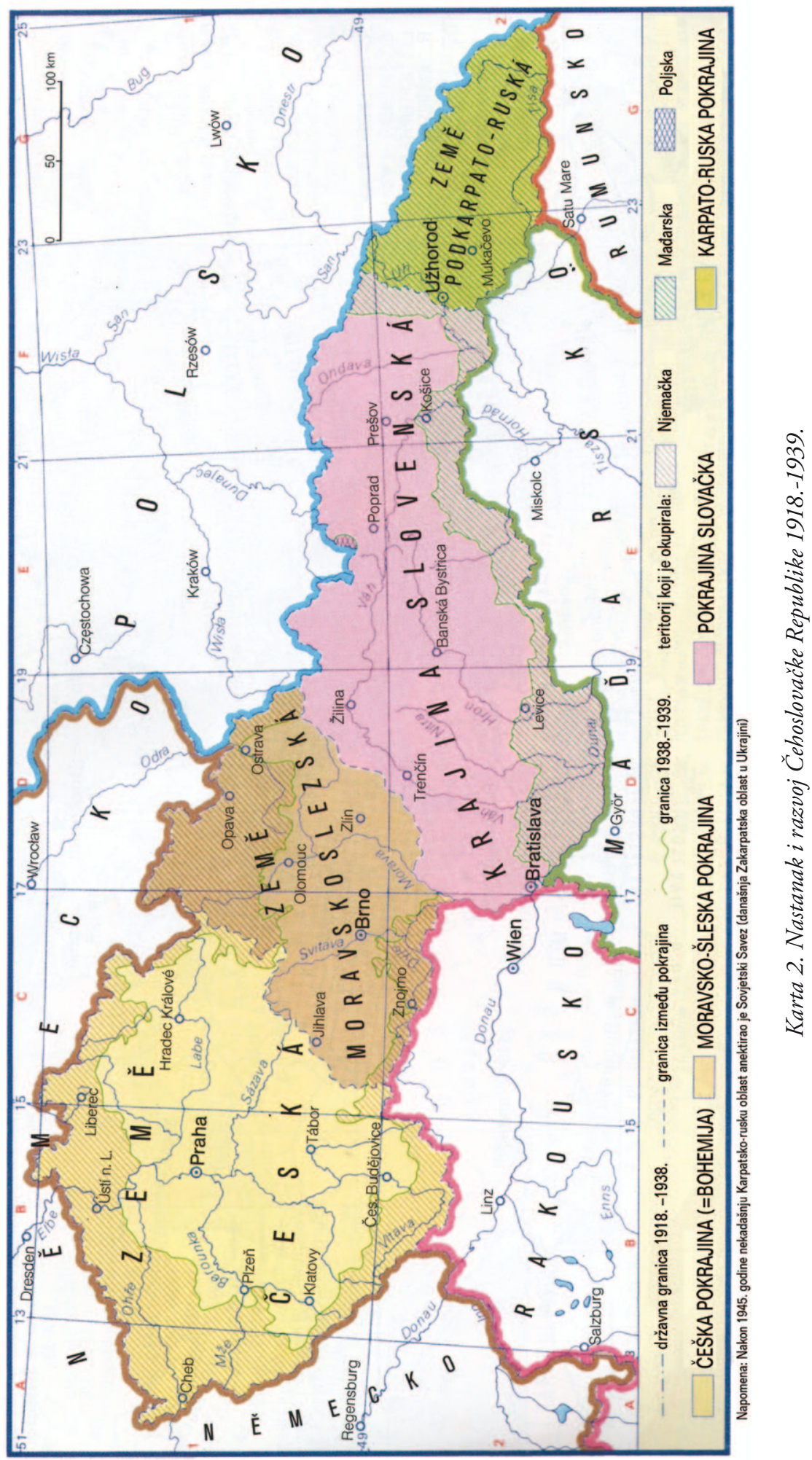

